\title{
Physico-chemical and sensorial evaluation of new varieties of acerola
}

\author{
M.E.O. Mamede and M.P.S. Miranda \\ Federal University of Bahia, Bahia, Brazil \\ R. Ritzinger and R.C.B. Godoy \\ Embrapa Cassava and Tropical Fruits, Cruz das Almas, Bahia, Brazil, and \\ E.S. Velozo \\ Federal University of Bahia, Bahia, Brazil
}

\section{Physico-chemical and sensorial evaluation}

\begin{abstract}
Purpose - The purpose of this paper is to evaluate the chemical, physical and sensory composition of three new varieties of acerola (Rubra, Cabocla and CMF 017).

Design/methodology/approach - The samples of ripe acerola were collected from the Active Germoplasm Bank of Embrapa Cassava and Tropical Fruits - Cruz das Almas/Bahia, from the species Malpighia emarginata DC and analyzed by using standard methods.

Findings - The findings were that the Rubra variety stood out among the others in terms of flavour and purchasing intention, probably due to its $\mathrm{pH} 3.60$, total acid ( 0.83 percent malic acid) and Vitamin C (911.97g ascorbic acid/100 g) which gave the variety a less acidic flavour. As regards size, the average acceptability of this variety was 6.01, statistically different from Cabocla (8.08). Total anthocyanins were also found to be the highest, $76.7 \mathrm{mg} / 100 \mathrm{~g}$ and therefore the antioxidant activity of the peel was greater (85 percent) compared with the other varieties, though not differing statistically from the CMF 017 variety. According to these results, the Rubra variety is the one which should be of most interest to producers.

Practical implications - The new variety often fails to exceed nutritional and organoleptic characteristics of existing varieties in the market with established acceptance levels. The paper evaluates the chemical and sensorial composition of new varieties of acerola fruit, which could be launched on to the market. It was observed that one particular variety had better sensorial and nutritive quality.

Originality/value - This kind of data is important both for consumers who want to buy the best quality fruit and producers who want to plant more of the better quality variety so that they can gain greater added-value in the commercialization of the fruit.
\end{abstract}

Keywords Brazil, Fruits, Vitamins

Paper type Research paper

\section{Introduction}

Acerola, also known as the Antilles cherry, belongs to the Malpighiaceae family genus Malpighia. The most commonly cultivated acerola in Brazil is the species Malpighia emarginata DC (Oliveira et al. 2003). Depending on the variety, it can be round, oval or even conical in shape and the pigmentation of its skin can vary from orange to purple according to the presence of anthocyanins (Carvalho and Manica, 1993).

The authors would like to thank Embrapa Cassava and Tropical Fruits, Cruz das Almas, Bahia, Brazil for donating the fruit samples.

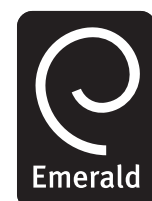

British Food Journal Vol. 111 No. 4, 2009 pp. 387-395 (C) Emerald Group Publishing Limited 0007-070X DOI 10.1108/00070700910951867 
$\mathrm{BFJ}$

111,4

388

Some authors have found anthocyanin values of between $3.79 \mathrm{mg} / 100$ and $59.74 \mathrm{mg} / 100 \mathrm{~g}$ in the skin depending on the variety of acerola (Lima et al., 2003). Malvidin, pelargonidin and cyanidin have been mentioned as the principal anthocyanins present in acerola (Silva et al., 1998). Anthocyanins not only provide the colour for flowers, fruits and roots but they are also powerful antioxidants (Francis, 1989). The antioxidant activity of these compounds is linked to their chemical structure, or more precisely to groups of hydroxyl present in the rings A and B (Rice-Evans et al., 1996).

Furthermore, acerola stands out among other fruits for having a particularly high vitamin C content, which can vary between 1,000 and 1,677.5 mg/100 g (Philippi, 2001). These amounts are considerable when compared to oranges, which have $54 \mathrm{mg} / 100 \mathrm{~g}$ (Tabela Brasileira de Composição de Alimentos (TACO), 2004). Vitamin C is also considered to be a powerful antioxidant with free radicals. Antioxidants can inhibit or slow down oxidative reactions and are therefore important compounds in the prevention of certain types of cardiovascular diseases, cancer, inflammations, Parkinson and Alzheimer's diseases (Halliwell, 2000; Aruoma, 1998).

Nowadays Brazil is the largest producer, consumer and exporter of acerola (Cecílio et al., 2004). The biggest producers of acerola at state level are: Pernambuco which produces 23.11 percent, followed by Ceará with 14.32 percent, Sao Paulo with 11.39 percent and Bahia with 10.48 percent. The Northeast region of the country is responsible for 69.6 percent of production. Both the soil conditions and the climate of the Northeast lend themselves to the production of an excellent quality fruit all year round, suitable for supply to the European, Asian and American market at any time of the year. This has led to the setting up of large agro-industrial undertakings bringing jobs to the poor semi-arid regions of the country. Some of the pre-requisites for export to Europe and Japan include a total solid soluble content of equal to or greater than $7.0^{\circ}$ Brix, vitamin $\mathrm{C}$ content of over $1,000 \mathrm{mg}$ ascorbic acid/100 $\mathrm{g}$ of pulp (Alves, 1996).

New varieties of acerola have emerged in the search for greater resistance to disease and pests and mechanical damage, to enhance colour, size and to alter the composition of its chemical components, etc. Genetic improvements mainly aim to modify the negative characteristics of the product but inevitably end up modifying the positive characteristics such as the components responsible for taste and aroma. Sensory analysis is being increasingly used to evaluate the quality of new varieties of fruits "in natura" (Matsuura et al., 2002; Santana et al., 2004(. This is because the sensory qualities are as important for the consumer as size, disease resistance and price are for the producer. This work analysed the chemical constituents and the sensorial acceptability of three new varieties of acerola collect in the month of November. The preliminary results of the sensorial acceptability, chemical and physical data of fruit collected one occasion (November) are presented.

\section{Material and methods \\ Materials}

The samples of ripe acerola (three varieties: CMF 017, RUBRA, CABOCLA) were collected from the Active Germoplasm Bank of Embrapa Cassava and Tropical Fruits - Cruz das Almas/Bahia, from the species Malpighia emarginata DC. The fruit (approximately $3 \mathrm{~kg}$ ) was collected without stems, washed and dried. Immediately thereafter, sensorial, chemical and physical analyses were carried out and then after 48 
hours in a freezer at $-20^{\circ} \mathrm{C}$ the antioxidant activity, total anthocyanins and flavonols analyses. Ten fruits of each variety were weighed and diameter of the fruit was measured using a micrometer.

\section{Methods}

Physico-chemical analysis

From the whole fruit, a pulp was made. The following parameters were measured using this pulp:

- Measurement of $\mathrm{pH}$ - The $\mathrm{pH}$ of the pulp was determined by using digital $\mathrm{pH}$ meter.

- Total soluble solids - TSS were determined by using refractometer and the results expressed as ${ }^{\circ}$ Brix, Method 932.14C (AOAC, 1990).

- Titratable acidity - was carried out using AOAC method no. 942.15, 1990, and results expressed in malic acid percent.

- Vitamin $C$ - by titrimetry with 2,6 Diclorophenol indolphenol, Tillman method (Lees, 1975).

This analysis was done in triplicate and data were analyzed by analysis of variance (ANOVA) and Tukey test, employing SAS Software (1997).

\section{Sensory analysis}

The acceptability tests for the attributes aroma, flavour, colour, succulence and size were carried out by 50 consumers who said they liked acerola. The analyses were carried out in booths and with lighting. All the samples were codified with digit numbers. A $9 \mathrm{~cm}$ non-structured hedonic scale was used for each attribute and the purchasing intention was recorded on a five-point attitude scale on the same score sheet (Meilgaard et al., 1983; Stone and Sidel, 1993). Statistical analysis was carried out using Analysis of Variance (ANOVA) and Tukey test, employing SAS Software (1997).

\section{Extraction and measurement of total anthocyanins and flavonols}

The extraction and measurement of total anthocyanins and flavonols in the skin of $400 \mathrm{~g}$ of acerola were carried out according to Lee and Francis (1972) in triplicate. Absorbance readings were done at 535 and $374 \mathrm{~nm}$ to quantify the total anthocyanins and flavonols respectively. The absorbance coefficient used was 98.2 for anthocyanins and 76.6 for flavonols (Lee and Francis, 1971). The data were analyzed by ANOVA and Tukey test, employing SAS Software (1997).

\section{Analysis of anthocyanidins}

The extract of anthocyanins was heated to $60^{\circ} \mathrm{C}$ in a vacuum to obtain the anthocyanidins in triplicate. The separation of the pigments was carried out in chromatographic paper used WHATMAN no. 3 paper. O The mobile phase was BAW (butanol, acetic acid and water in proportion 4:1:5 (v/v). The identification was done by comparing the retention times, and, also specific reactions with the $\mathrm{AlCl}_{3}$ (Harbone, 1973). The data were analyzed by average and standard deviation.

\section{Physico-chemical and sensorial evaluation}

389 
$\mathrm{BFJ}$

111,4

390
Antioxidant activity - $\beta$-carotene-linoleic acid assay

In this work the anti-oxidative capacity of the composition of the skin for the acerola were determined by the inhibition of conjugated diene hydroperoxides arising from linoleic acid oxidation. A solution of $\beta$-carotene-linoleic acid was prepared according to Dapkevicius et al. (1998) in triplicate. Quantities of $200 \mu \mathrm{L}$ of an extract of anthocyanins, obtained of the skin of $400 \mathrm{~g}$ of acerola, were incubated with $5 \mathrm{ml}$ of the $\beta$-carotene-linoleic acid emulsion for 120 minutes at room temperature. After this incubation period, absorbances of the mixtures were measured at $470 \mathrm{~nm}$. The same procedure was repeated with the synthetic anti-oxidant, butylated hydroxytoluene (BHT) as positive control, and a blank. The anti-oxidative capacities of the extracts were compared with those of BHT and blank. The results were expressed in percentages of anti-oxidative capacity. The data were analyzed by ANOVA and Tukey test, employing SAS Software (1997).

\section{Results and discussion}

Physico-chemical composition

Acerola is an acidic fruit with a pH of between 3.11 and 3.41 (Musser, 2001). The $\mathrm{pH}$ for the variety CMF 017 was 3.29 and for the Rubra variety 3.60 . These results show that the new varieties have a pH above the minimum (3.11) and the maximum (3.41) found by Musser (2001). Total acidity also reflects the $\mathrm{pH}$, as the higher the $\mathrm{pH}$, the lower the total acidity (Table I). The Rubra variety has a higher $\mathrm{pH}$ and therefore a lower acid content $(0.83 \mathrm{~g} / 100 \mathrm{~g}$ malic acid).

The Rubra variety stood out in terms of Total Soluble Solids (TSS) $\left(8.840^{\circ}\right.$ Brix), compared to CMF 017 and Cabocla. The variety CMF-017 and Cabocla had lower TSS and there was no significant difference between them. These amounts were different from those reported by França (1999) and Musser (2001) in other varieties. The amounts found for the varieties studied, were all within the limits required, by the Japanese and European market, the biggest importers of the product.

The average vitamin $\mathrm{C}$ content, expressed in ascorbic acid in the three varieties was near or above the levels recommended by the breeding program, in other words higher than 1,000 $\mathrm{mg}$ ascorbic acid/100 $\mathrm{g}$ (Table I). Compared to other fruits, acerola has other advantages: the vitamin $\mathrm{C}$ content and the number of calories. The guava, for example, has $217.6 \mathrm{mg} / 100 \mathrm{~g}$ ascorbic acid, but it generates $69 / 100 \mathrm{~g}$, while acerola has levels of

\begin{tabular}{lrcr}
\hline Varieties & CMF-017 & Cabocla & Rubra \\
\hline pH & $3.29^{\mathrm{c}}$ & $3.46^{\mathrm{b}}$ & $3.60^{\mathrm{a}}$ \\
SST & $7.88^{\mathrm{b}}$ & $8.02^{\mathrm{b}}$ & $8.84^{\mathrm{a}}$ \\
${ }^{\circ}$ Brix & & & $1.11^{\mathrm{b}}$ \\
ATT & $1.36^{\mathrm{a}}$ & $7.27^{\mathrm{b}}$ & $0.83^{\mathrm{c}}$ \\
Percent malic acid & $5.84^{\mathrm{a}}$ & & $10.72^{\mathrm{a}}$ \\
SST/ATT & & $1,052.23^{\mathrm{ab}}$ & $911.97^{\mathrm{b}}$ \\
Vitamin C & $1,191.91^{\mathrm{a}}$ & $3.0^{\mathrm{b}}$ & $2.4^{\mathrm{a}}$ \\
g ascorbic acid/100g & $2.5^{\mathrm{a}}$ & $9.0^{\mathrm{b}}$ & $6.7^{\mathrm{a}}$ \\
Diameter (cm) & $6.5^{\mathrm{a}}$ & &
\end{tabular}

Physico-chemical data of the acerola varieties
Note: Means within a line followed by same letters do not differ significantly by Tukey test $(p<0.05)$ 
ascorbic acid, which are at least four times higher $(911.9 \mathrm{mg} / 100 \mathrm{~g}$ ascorbic acid in the Rubra variety) and in $100 \mathrm{~g}$ it produces only 32 calories. Thanks to this, acerola has been described as both a "functional" and "light" fruit.

\section{Sensory evaluation and correlations}

The average acceptability for flavour, between 5.12 and 6.43, which corresponds to "quite liked" and "liked moderately", revealed that the samples had acceptability above the descriptor "neither liked nor disliked", i.e. the data did not show any doubts in acceptability. The Rubra variety had greater levels of acceptability for flavour (6.43, see Table II) and also the highest purchasing intention for the descriptor "definitely would buy" (Figure 1). However, this variety had the lowest vitamin C content and the highest $\mathrm{pH}$ value. These chemical characteristics probably give the variety a less acid taste than the others. The variety CMF 017 had the highest vitamin $\mathrm{C}$ content (1191.91 $\mathrm{mg}$ ascorbic acid/100 $\mathrm{g}$ of pulp) and the lowest average acceptability of all the varieties (5.12) for the attribute flavour. The high concentration of vitamin C lowers the $\mathrm{pH}$ and makes the fruit particularly acid. The Cabocla variety was between the other two varieties in terms of vitamin $\mathrm{C}$ content, however, it had the highest average acceptability for aroma (6.77, see Table II).

\begin{tabular}{lccc}
\hline Attributes & CMF 017 & $\begin{array}{c}\text { Mean acceptability } \\
\text { Cabocla }\end{array}$ & Rubra \\
\hline Flavour & $5.12^{\mathrm{b}}$ & $5.56^{\mathrm{ab}}$ & $6.43^{\mathrm{a}}$ \\
Aroma & $4.84^{\mathrm{a}}$ & $6.77^{\mathrm{bc}}$ & $5.46^{\mathrm{ca}}$ \\
Size & $5.11^{\mathrm{a}}$ & $8.08^{\mathrm{b}}$ & $6.01^{\mathrm{ac}}$ \\
Succulence & $5.12^{\mathrm{a}}$ & $5.85^{\mathrm{a}}$ & $5.77^{\mathrm{a}}$ \\
Colour & $6.0^{\mathrm{a}}$ & $6.4^{\mathrm{a}}$ & $5.39^{\mathrm{a}}$
\end{tabular}

Note: Means within a line followed by same letters do not differ significantly by Tukey test $(\phi<0.05)$

\section{Physico-chemical and sensorial evaluation}

391

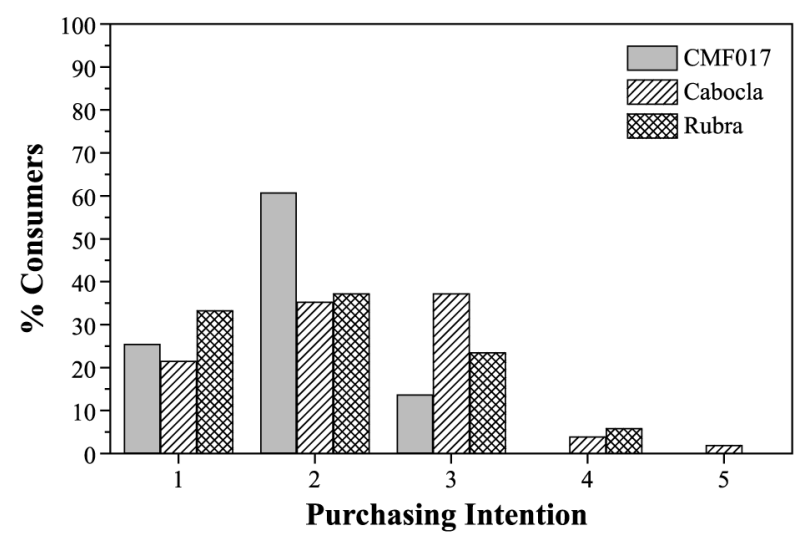

Note: 1- definitely would buy; 2- probably would buy; 3 - maybe/maybe not; 4- probably would not buy; 5 - definitely would not buy

\section{Figure 1.}

Consumer purchasing intention of varieties of acerola (November 2005) 
$\mathrm{BFJ}$

111,4

392

Among the three varieties studied Cabocla was the largest with an average diameter of $30 \mathrm{~cm}$, while Rubra and CMF 017 were $25 \mathrm{~cm}$ in diameter. As regards size acceptability, Cabocla had the highest average (8.08). Given the size of the variety Cabocla, one would expect higher purchasing intention for the descriptor "definitely would buy", but the variety had only a 22 percent purchasing intention for this descriptor. The highest purchasing intention was reported for the Rubra variety (33 percent), while the CMF 017 had 25 percent. The variety Rubra had the highest purchasing intention for the descriptor "definitely would buy", although its size was smaller than the Cabocla variety. Given this, we can see that appearance, the consumers' first observation of the product, was not a decisive factor in purchasing intention. It was probably flavour, which was the most important attribute for the consumers' decision to purchase, as the Rubra variety had higher levels of acceptability for this attribute (6.43). The consumers were unable to detect any significant difference between the colour and succulence in any of the samples.

\section{Antioxidant activity and correlations}

Table III shows the percentages of antioxidant activity for the varieties studied. The antioxidant activity percentage is the sum of the activity of all the compounds which act as antioxidants, such as anthocyanins, flavonols and vitamin C. However, while the Rubra variety has a lower concentration of vitamin C, $911.97 \mathrm{~g}$ ascorbic acid/100 g (Table I), it has the highest concentrations of anthocyanins and total flavonols, $76.7 \mathrm{mg} / 100 \mathrm{~g}$ and $44.9 \mathrm{mg} / 100 \mathrm{~g}$ respectively (Table III). The high percentage of antioxidant activity of the variety Rubra is probably due to the high content of anthocyanins and total flavonols found in it. The Cabocla variety had the lowest antioxidant activity (71 percent). Table III shows that the varieties studied here had higher concentrations of anthocyanins than other varieties that have been studied elsewhere. The variety Rubra had a concentration of $76.7 \mathrm{mg} / 100 \mathrm{~g}$ total anthocyanins, whereas Lima et al. (2003) registered a maximum of $59.74 \mathrm{mg} / 100 \mathrm{~g}$ in one of the varieties studied.

\section{Anthocyanidin composition of acerolas}

The study of anthocyanidin (aglycones) is important for the pigmentation of vegetables and fruit. The compounds can be extracted from them, as is the case with $\beta$-carotene extracted from carrots, which have large concentrations of this compound.

Chromatographic analysis of anthocyanidin showed clear results given the limitations of chromatographic on paper. Although, there was a small formation of a tail, which meant we were able to identify the aglycones to compare retention time. In the three varieties studied in triplicate the presence of cyanidin was verified, as

Table III.

Antioxidant activity, quantification of total anthocyanins and flavonols

\begin{tabular}{lccr}
\hline & CMF 017 & Cabocla & Rubra \\
\hline Antioxidant activity $(\%)$ & $83.0^{\mathrm{a}}$ & $71.0^{\mathrm{b}}$ & $85.0^{\mathrm{a}}$ \\
Total anthocyanins $(\mathrm{mg} / 100 \mathrm{~g})$ & $57.1^{\mathrm{a}}$ & $13.0^{\mathrm{b}}$ & $76.7^{\mathrm{c}}$ \\
Total flavonols $(\mathrm{mg} / 100 \mathrm{~g})$ & $36.5^{\mathrm{a}}$ & $22.5^{\mathrm{b}}$ & $44.9^{\mathrm{c}}$
\end{tabular}

Note: Means within a line followed by same letters do not differ significantly by Tukey test $(\phi<0.05)$ 


\begin{tabular}{|c|c|c|c|}
\hline Pigment & $R F^{\mathrm{a}}(\times 100)$ & $R F^{\mathrm{b}}(\times 100)$ & \multirow{2}{*}{$\begin{array}{r}\text { and sensorial } \\
\text { evaluation }\end{array}$} \\
\hline Cyanidin & 68 & $68.4 \pm 0.5$ & \\
\hline Delphinidin & 42 & - & \\
\hline Malvidin & 58 & $57.0 \pm 1.5$ & \\
\hline Pelargonidin & 80 & $79.0 \pm 1.5$ & \\
\hline Peonidin & 71 & $71.5 \pm 0.9$ & 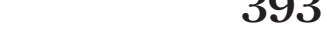 \\
\hline Petunidin & 52 & $51.0 \pm 1.1$ & Table IV. \\
\hline \multicolumn{3}{|c|}{$\begin{array}{l}\text { Notes: } R F^{\mathrm{a}}=\text { Harbone, } 1973 \text { (solvent BWA = butanol/acetic acid/water } 4: 1: 5 \mathrm{v} / \mathrm{v} \text { ) and } R F^{\mathrm{b}}=\text { Food } \\
\text { and Drinks Research Laboratory - Faculty of Pharmacy - UFBA, using the same solvent }\end{array}$} & $\begin{array}{l}\mathrm{RF} \text { values of the main } \\
\text { anthocyanidins, from } \\
\text { paper chromatography }\end{array}$ \\
\hline
\end{tabular}

expected as the presence of this pigment had been previously reported in acerolas (Silva et al., 1998). The $R F$ value was very similar to that found for this pigment (cyanidin) in the literature in the same chromatographic conditions (Table IV). The band with $R F$ value $=68.4 \pm 0.5$ was cut and eluted with methanol and treated with $\mathrm{AlCl}_{3}$. This treatment revealed a bathochromic shift dislocation indicating the presence of cyanidin. The presence of malvidin and pelargonidin, by $R F$ value comparison, was confirmed for the Cabocla variety alone, while only the varieties Rubra and CMF 017 the presence of petunidin and peonidin was confirmed. The variety Rubra, which has the greatest concentration of total anthocyanins (Table III), could be a rich source for the extraction of anthocyanins such as petunidin, peonidin and cyanidin. We would suggest further analysis with HPLC and identification of these compounds using pure standards.

\section{Conclusion}

As regards the chemical composition, all the varieties have vitamin $\mathrm{C}$ and SST contents near or above the lower limits set for export.

The variety Rubra can be used as a source for the extraction of petunidin, peonidin and cyanidin, however, we suggest liquid chromatography analysis to complement this.

The results of the sensory analysis can be used by producers of Acerola as a tool to obtain data regarding the quality of fruit. However, few producers make use of this tool in the choice of which variety to cultivate and instead use criteria such as resistance to disease. Awareness-raising among farmers as to the importance of sensorial analysis and the correlation of the result with chemical analysis would be useful in the search for a high quality fruit in all aspects. The variety Rubra, for example, could be more widely cultivated among Acerola producers as it revealed the highest purchasing intention, greatest acceptability in terms of taste as well as the highest antioxidant activity, and therefore it is the variety which is the most powerful deactivator of free radicals.

\section{References}

Alves, R.E. (1996), "Características das frutas para exportação", in Gorgatti-Netto, A., Ardito, E.F.G., Garcia, E.E.C., Bleinroth, E.W., Freire, F.C.O. and Menezes, J.B. (Eds), 
$\mathrm{BFJ}$

111,4

394
Acerola para exportação: procedimentos de colheita e pós-colheita, (Série Frupex, 21), Embrapa-JPI, Brasília, pp. 9-21.

AOAC (1990), Official Methods of Analysis, Association of Official Analytical Chemists, Washington, DC, Vol. 2, pp. 912, 1010-11.

Aruoma, O.I. (1998), "Free radicals, oxidative stress and antioxidants in human health and disease”, Journal American Oil Chemical Society, Vol. 75, pp. 199-212.

Carvalho, R.I.N. and Manica, I. (1993), “Acerola: composição e armazenamento de frutos”, (Cadernos de Horticultura, 1), Universidade Federal Rio Grande do Sul, Porto Alegre, pp. 1-7.

Cecílio, R.A., Medeiros, S.S. and Silva-Júnior, J.L.C. (2004), “Aptidão agroclimática para o cultivo da acerola na Bahia”, Bahia Agricola, Vol. 6 No. 3, pp. 20-3.

Dapkevicius, A., Venskutonis, R., Van Beek, T.A. and Linssen, P.H. (1998), “Antioxidant activity of extracts obtained by different isolation procedures from some aromatic herbs grown in Lithuania”, Journal of the Science of Food Agriculture, Vol. 77, pp. 140-6.

França, V.C. (1999), "Características físicas, químicas e desenvolvimento de produtos de acerola (Malpighia emarginata DC)", dissertation of Ms, UFJP, João Pessoa.

Francis, F.J. (1989), "Food colorants: anthocyanins", Critical Review Food Science Nutrition, Vol. 28 No. 4, pp. 273-314.

Halliwell, B. (2000), "Lipid peroxidation, antioxidants and cardiovascular disease: how should we move forward?”, Cardiology Research, Vol. 47 No. 1, pp. 410-18.

Harbone, J.B. (1973), Phytochemical Methods - a Guide to Modern Techniques of Plant Analysis, Chapman \& Hall, London, pp. 7-33.

Lee, D.H. and Francis, F.J. (1971), "Quantitative methods for anthocyanins. VI. Flavonols and anthocyanins in fresh cranberries", Journal of Food Science, Vol. 36, pp. 1056-60.

Lee, D.H. and Francis, F.J. (1972), "Standardization of pigment analyses in cranberries", HortoScience, Vol. 7, pp. 83-4.

Lees, R. (1975), Food Analysis and Quality Control Methods for the Food Manufacturer and Buyer, Leonard Hill Books, London.

Lima, V.L.A.G., Melo, E.A., Maciel, M.I.S. and Lima, D.E.S. (2003), “Avaliação do teor de antocianinas em polpa de acerola congelada proveniente de frutos de 12 diferentes aceroleiras (Malpighia emarginata DC)", Ciência e Tecnologia de Alimentos, Vol. 23 No. 1, pp. 101-3.

Matsuura, F.C.A.U., Cardoso, R. and Ribeiro, D.E. (2002), "Qualidade sensorial de frutos de híbridos de bananeira Cultivar pacovan”, Revista Brasileira de Fruticultura, Vol. 24 No. 1, pp. 263-6.

Meilgaard, G.K., Civille, G.V. and Carr, B.I. (1983), Sensory Evaluation of Foods: Marketing and $R \& D$ Approaches, Food \& Nutrition Press, Westport, CT, pp. 230-45.

Musser, R.S. (2001), "Caracterização de acessos de aceroleira (Malphigia emarginata DC) do Banco Ativo de Germoplasma da UFRPE”, dissertation of PhD, UFRPE, Recife.

Oliveira, J.R.P., Soares-Filho, W., Kobayashi, A.K. and Ritzinger, R. (2003), "A cultura da Aceroleira”, in Ritzinger, R., Kobayashi, A.K. and Oliveira, J.R.P. (Eds), Aspectos Botânicos, Embrapa Mandioca e Fruticultura, Cruz das Almas, pp. 1-198.

Philippi, S.T. (2001), Tabela de Composição de Alimentos: suporte para decisão nutricional, FINATEC/NUT-Universidade de Brasilia/UNB, Anvisa. 
Rice-Evans, C., Nicolas, J., Miller, J. and Paganga, G. (1996), "Structure-antioxidant activity relationships of flavonoids and phenolic acids", Free Radical Biology and Medicine, Vol. 20, pp. 933-56.

Santana, R.R.L., Matsuura, F.C.A.U. and Cardoso, R.L. (2004), "Genótipos melhorados de mamão (carica papaya L.): avaliação sensorial e físico-química dos frutos", Ciência e Tecnologia de Alimentos, Vol. 24 No. 2, pp. 217-22.

Silva, M.F.V., Menezes, H.C. and Guedes, M.C. (1998), "Caracterização dos pigmentos antociânicos de diferentes cultivares de acerola (Malpighia glabra) por CLAE", Latin and sensorial evaluation American Congresso on Chromatography, p. 155.

Stone, H.J. and Sidel, J.L. (1993), Sensory Evaluation Practices, Academic Press, London.

Tabela Brasileira de Composição de Alimentos (TACO) (2004), NEPA-UNICAMP, Tabela Brasileira de Composição de Alimentos (TACO), Campinas, pp. 1-42.

\section{Further reading}

Lima, V.L.A.G., Melo, E.A., Maciel, M.I.S., Prazeres, F.G., Musser, R.S. and Lima, D.E.S. (2005), "Total phenolic and carotenoid contents in acerola genotypes harvested at three ripening stages", Food Chemistry, Vol. 90, pp. 565-8.

\section{Corresponding author}

M.E.O. Mamede can be contacted at: mmamede@ufba.br

To purchase reprints of this article please e-mail: reprints@emeraldinsight.com Or visit our web site for further details: www.emeraldinsight.com/reprints 